\title{
REVIEW
}

\section{Trends in the Characterization Methods of Orodispersible Films}

\author{
Garba M. Khalid, Francesca Selmin, Umberto M. Musazzi, Chiara GM Gennari, Paola Minghetti \\ and Francesco Cilurzo*
}

Department of Pharmaceutical Sciences, Università degli Studi di Milano, via G. Colombo, 71, 20133 Milan, Italy

\begin{abstract}
The recent increased interest in orodispersible films (ODF) stems from their ideal potential to circumvents several pharmacotherapy related problems, such as improved medication compliance and adherence especially in children, elderly and uncooperative patients. Their administration is well accepted by the majority of patients because ODF dissolve upon in contact with the saliva in the oral cavity without need of water intake. ODF application in personalized pharmacotherapy is currently being exploited. Moreover, innovative preparation methods and characterization technologies have been evolving in recent years, highlighting promising future both from the technological and clinical standpoints. However, the key obstacles to the attainment of full potentials of ODF in the pharmaceutical field is the lack of harmonized and well-defined quality characterization procedures, standard evaluation parameters, guidance on appropriate final product properties and specifications. This review provides an appraisal on the ODF characterization methods from slurries to the finished medicinal products with a specific focus on the technologies suitable for identification, quantification, and quality evaluation of extemporaneously prepared ODF on small batches in individualized pharmacotherapy. Generally, there is a paradigm shift from the use of the conventional quality evaluation tools and/or protocols for oral solid dosage forms to characterize ODF to more specific equipment and procedures that suit the peculiarities of the ODF.
\end{abstract}

Keywords: Orodispersible films, Non-destructive assay, Quality control, Mechanical properties, Personalized therapy.

\section{INTRODUCTION}

Orodispersible dosage forms provide the opportunity to meet the special needs of specific subpopulation of patients suffering from a variety of disorders, among which swallowing difficulties (dysphagia), Parkinson's disease, psychosis, thyroid disorder, stroke, and multiple sclerosis are the most relevant [1]. In addition, children and elderly, and patients with limited access to water can also benefit from their advantages [2,3]. Since orodispersible dosage forms came onto the market in the 80s, their development has grown gradually, moving from orodispersible tablets (ODT) to orodispersible films (ODF) which present the undoubtedly advantages to completely eliminate the fear of choking [3,4]. Moreover, pharmaceutical companies have invested in these dosage forms because they can extend their product portfolio and ODF can be marketed easily as line-extensions. The possibility to change shape and color of the ODF have open new scenarios to prepare small batches for personalization of

*Department of Pharmaceutical Sciences, Università degli Studi di Milano, Via G. Colombo 71, 20133, Milano, Italy; Tel: +39-0250324635; E-mail: francesco.cilurzo@unimi.it the dose in special patient population [5].

ODF are generally made up of plasticized hydrocolloids or blends made thereof that can be laminated by several techniques and sealed in a moisture-protective package [3]. The active pharmaceutical ingredient (API) can be dissolved or dispersed as such or as nanocrystals [6] or loaded into microparticles [7] depending on the physicochemical properties of the drug and the desired release pattern. Other components can be surfactants, viscosity modifiers, tastemasking agents and coloring agents, when required $[2,5,8]$.

ODF are prepared by solvent-based or melting-based technique even if, for the purpose of personalized therapy, different types of ODF printing technologies have been proposed [8].

Independently of the batch size, the main critical quality attributes are related to disintegration time, drug dissolution rate, tensile properties and taste evaluation [3,9]. The European Pharmacopeia (Ph. Eur.) states that ODF should disintegrate within 3 min with reference to ODT, even though, the disintegration time of ODF usually ranges from 10 to 60 seconds [3], but most of the other ODF quality attributes are yet to be categorically defined and most quality controls are related to ODT [10]. The development of small batches has 
also pointed out that non-destructive and versatile analytical methods are also required [8].

In this work, we appraised the current literature on the ODF characterization methods from slurries to the finished medicinal products, referred both to industrial mass production and small-scale on demand ODF for personalized therapy. In this context, the description of compendial and non-compendial methods required to demonstrate the quality and the acceptance criteria of an ODF produced industrially or prepared in a pharmacy setting are pointed-out.

To fulfill this aim, the references were extracted from SCOPUS and Web of Science databases by matching the following keywords: Orodispersible film, Fast dissolving film, Oral thin film, Quality assessment, Quality control, Characterization, Assay, Non-destructive, Disintegration, In vitro dissolution, and Mechanical properties.

\section{Characterization of the slurries used for film}

\section{preparation}

Regardless of the preparation methods, the rheological characterization of slurries containing all the formulation components is of high significance to rationalize the design space of ODF formulation.

Highly viscous slurries for casting can entrap air bubbles which can create defects in the dried film and affect the uniformity of drug contents $[11,12]$. However, the presence of air bubbles could be minimized by stirring the slurry under vacuum, centrifugation, using degassed water [13], sonication, or storing the slurry in a refrigerator for a defined period of time [11]. Moreover, to limit the entrapment of air bubbles, the film-forming material can be preliminarily dispersed in a medium and then mixed with the solution/slurry containing other excipients including surfactant(s) [12]. Low viscous slurries can limit the content uniformity because the mass may lead to running of the slurry in a direction opposite to the coating process directly after coating the liner [11] or, in case of suspended API, sedimentation may occur before casting [14]. It is worthy of note that also the fraction of suspended API can increase the slurry viscosity. As an example, Woertz and Kleinebudde demonstrated that relative viscosity of the suspension is independent of the type of cellulose derivative used, but dependent on the fraction of loperamide and ibuprofen [12]. Another requirement of slurries to be cast is the wettability onto the backing layer to avoid its shrinkage and, therefore, the uniformity of content and ODF appearance. To modify the contact angle between slurry and the backing layer, surfactants and/or thickening agents are generally added [2,15]. Moreover, the backing layer should be carefully selected on a case-by-case basis depending on the composition of the drug-polymer mixture bearing in mind the role of surface-active agent and thickening agents. As an example, a surfactant with low HLB (i.e. sorbitan oleate) was necessary to uniformly spread slurries made of maltodextrins and glycerin onto the silicone release liner [14].

Also, in case of HME, the viscosity of the melt affects the consistency and printability of an ODF. Again, in the case of maltodextrins, the shear viscosity data indicated that the plasticizer amount was more relevant than the polymer molecular weight [5].
In case of the ink-jet printing, the critical aspects to be optimized are viscosity and surface tension [8]. First, the viscosity should be low enough that the fluid can be jetted out, but sufficiently high that the fluid is not ejected too early, which can lead to the formation of satellite droplets [16]. Similarly, the surface tension is expected to be high enough to enable the formation of spherical droplets and to resist leakage from the print head when the printer is in stand-by. Poorly optimized and inconsistent viscosity and/or surface tension of the ink solution can clog nozzles decreasing the uniformity of printing viz a viz reducing the drug content uniformity $[8,17]$. Additionally, viscosity and surface tension also affect the refilling phase of the drop generator as the solution passes through spouts into the nozzle firing chambers. Depending on the requirements of the print head manufacturer, the dynamic viscosity and the surface tension range $8-20 \mathrm{mPa} * \mathrm{~s}$ and 24 $36 \mathrm{mN} / \mathrm{m}$, respectively [17].

Data on the viscosity of polymer solutions are also reported in the case of continuous working pilot-scale coating bench to avoid unintentional flows of solution at the wrong side of the coating knife without forming a film on the intermediate liner. In this case, the value of $1 \mathrm{~Pa}^{*} \mathrm{~s}$ was optimal [18]. Consequently, adjustment can be done in terms of polymer concentration, or adding viscosity modifiers, such as glycerol and polyethylene glycol (PEG) [18].

\section{ODF characterization}

\subsection{Thickness and weight variation}

In general, ODF exhibits a thickness between 50 and 1000 $\mu \mathrm{m}$ depending on the loaded API [19], polymer [20] and plasticizer [21]. Even if it is not a golden rule, too thick ODF could have a prolonged disintegration time and too thin exhibit poor mechanical properties.

The measurement of ODF thickness uniformity is directly related to the film weight and, therefore, to the uniformity of dose [19]. The thickness is usually measured offline using a well-calibrated electronic digital micrometer, scanning electron photomicrography, screw gauge, or by vernier caliper. There are some online detection systems, such as backscatter sensors, that employs an in-line chromatic confocal measurement system to determine the wet film thickness in continuous manufacturing processes [22].

\subsection{Organoleptic evaluation}

Since these dosage forms disintegrate directly onto the oral cavity, suitable palatability is required. The taste masking strategy is selected considering that, compared to liquid formulations, the API in ODF is not diluted, and the formulation space is limited due to the low weight of the film. The effectiveness of taste-masking technique can be evaluated by in vitro and in vivo tests. The former uses taste sensors with an array of multichannel to mimic the conditions of taste buds in human tongues. These sensors are commonly called electronic tongues (e-Tongues, or ET). The popularity of these systems has been increasing in pharmaceutical fields due to rapidity, simplicity, relatively low cost, and lack of risks compared to human models [23]. ET is broadly divided into two categories. First, in the insent taste-sensing system, where the taste sensor output exhibits different patterns for chemical substances that have different taste qualities, mainly sweetness, bitterness, saltiness, sourness, and umami [24-26]. 
The second system consists of a quantitative taste sensor, such as the $\alpha$-ASTREE electronic tongue able to evaluate the overall taste of a product by using the output value from different electrodes. This taste sensor consists of an array of seven liquid cross-sensitive electrodes or sensors based on the ChemFET technology, an auto-sampler, and an associated interface electronic module. In the presence of dissolved compounds, a potentiometric difference is measured between each of the seven sensors and the $\mathrm{Ag} / \mathrm{AgCl}$ reference electrode $[27,28]$.

Despite these advantages, e-tongues cannot discriminate between one chemical flavour and another particularly for complex mixtures. Therefore, The palatability evaluation is generally carried out by trained taste panels of 4-15 people [29] in the age group of 18 to 30 years of both sexes to produce sensory profiles [23]. However, this procedure is complex due to ethical and toxicological considerations, especially when new drug substances are under investigation, and adult preferences are significantly different from children's taste. On the other hand, taste panels in children are nearly impossible because of ethical reasons and their inability to describe taste attributes and their preferences [24].

\subsection{Moisture content determination}

The residual water content needs particular attention because a certain amount of water can be desired to ensure the flexibility of the ODF and to circumvent brittleness [24]; but at the same time, a high amount can alter the mechanical properties and promote stickiness and microbiological bioburden or instability of the loaded API [5,30]. Even though the residual water content depends on the characteristics of film-forming material and the highest values reported in the literature (i.e. LOD $\sim 20 \%$ ) concerns the poly(methyl methacrylate)s where water acts as plasticizer [31].

The determination of water sorption and desorption profiles allows to estimate the ODF hygroscopicity and identify the role of APIs and/or excipients on the total water contents in the final product. High water sorption might be correlated to disintegration behavior, but also predicts the need of special packaging and storage conditions [24]. Usually, ODF are subjected to an initial drying stage from ambient to $0 \%$ relative humidity to ensure that percent changes in weight during the sorption-desorption cycle are on a dry weight basis. The dried sample is then subjected to a stepwise increase and decrease in relative humidity from 0 to $95 \%$ and 95 to $0 \%$, respectively at $25^{\circ} \mathrm{C}$. The total weight of water absorbed (sorption phase) and lost (desorption phase) are recorded [32-34].

However, the control of the environmental conditions (i.e. temperature and relative humidity) during preparation and/or production and the selection of an appropriate primary packaging material should be selected to avoid water exchange with the surrounding environments [33]. It is worth noting that, preservatives are sometimes included in ODF formulations to deter the microbial activities [24].

The quantification of residual water is generally obtained using thermogravimetry, infrared light balances, or Karl Fischer titration [32]. In some situations, thermogravimetric analysis (TGA) helps to define the type of water associated to the matrix. Moreover, the weight loss can be easily quantified and related dehydration, evaporation of low-boiling compounds or thermal degradation byproduct [10].

\subsection{Mechanical properties}

2.4.1. Tensile properties

The mechanical strength of ODF is considered of particular importance in up-scaled pharmaceutical manufacturing. Automated processes working on machines, such as rolls to transfer films from drying to storage or coiling up of ODF before cutting, requires sufficient robustness of the produced ODF without damage or breakage [24]. The European Pharmacopeia [35] specifies that ODF should 'possess suitable mechanical strength to resist handling without being damaged', but there is no further explanation on how to define a suitable mechanical strength of ODF, or what specific parameters should be measured with upper or lower limits. Since a standard method is yet to be established, mechanical properties are determined according to guidelines referred to the tensile properties of thin plastic sheeting and foil materials, namely ASTM D882 01 and DIN EN ISO 527, respectively. For instance, the ASTM D882 01 method consists of fixing an ODF specimen with a defined dimension between two clamps and pulling the upper clamp at a specific speed and applied force until it breaks [36]. For instance, a typical stress-strain curve for ODF Fig. 1 consists of 3 main regions namely; an initial linear elastic deformation of the film (left) as a result of the application of the stress, the second is the film necking due to stretching (center), and finally the film break or plastic deformation (right).

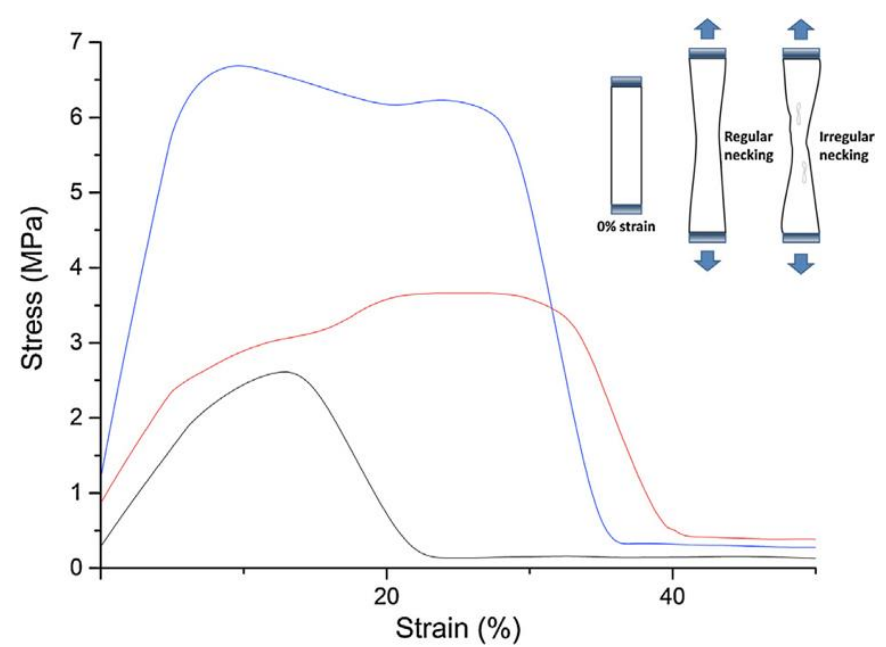

Figure 1. Typical stress-strain curve for ODF, adopted from [37].

From the stress-strain curve, the following parameters can be extrapolated and used to define the mechanical properties of an ODF:

Tensile strength (TS): is the resistance of the ODF to an applied force/stress prior to its break, or the maximum stress applied to a point at which the ODF specimen breaks. It is calculated by the maximum force at rupture $\left(\mathrm{F}_{\max }\right)$ divided by the initial cross-sectional area of the ODF (Area) as given in the equation (1):

$$
T S=\frac{F_{\max }}{\text { Area }}
$$


Young's modulus $\left(E^{\prime}\right)$ or elastic modulus is the measure of ODF stiffness. It is calculated as the slope of the linear portion of the stress-strain curve. Hard and brittle ODF generally possess higher tensile strength and higher Young's modulus values $[2,19]$.

Percent elongation at break $(\varepsilon)$ : application of stress on ODF specimen stretches its dimension and this is referred to as a strain. Percent elongation at break is determined by dividing the extension at the moment of rupture of the specimen $(\mathrm{L})$ by the initial gauge length of the specimen $\left(\mathrm{L}_{0}\right)$ and multiplying by 100 according to the following equation:

$$
\varepsilon=\frac{L-L_{0}}{L_{0}} \times 100
$$

Tensile energy to break (TEB) is defined by the area under the stress-strain curve (AUC) per unit volume of the ODF specimen between the clamps $\left(\mathrm{V}_{0}\right)$. In particular, $\mathrm{V}_{0}$ is calculated as a the product between the rectangular crosssectional area of the specimen and the original length of the sample between the clamps [31,38]. TBE values reflect the toughness of ODF. The value is in units of energy, and it is calculated as follows:

$$
T B E=\frac{\mathrm{AUC}}{V_{0}}
$$

\subsubsection{Tear resistance (TR) and puncture test}

Tear resistance (TR) measures of the ability of a sheet or film materials to resist tearing. This parameter is related to ODF ultimate resistance to rupture. Usually, a very low load speed of the texture analyzer $(51 \mathrm{~mm} / \mathrm{min})$ is employed and is designed to measure the force to initiate tearing of the ODF. The maximum stress, or force, required to tear the specimen is recorded as the tear resistance value in Newton [2].

On the other hand, puncture test measures the force needed to displace and, finally, to puncture the film [24]. As illustrated in Fig. 2, the ODF specimen is clamped in between two test plates with a cylindrical hole in the middle and the puncturing probe is moving down onto the film surface at a defined velocity.
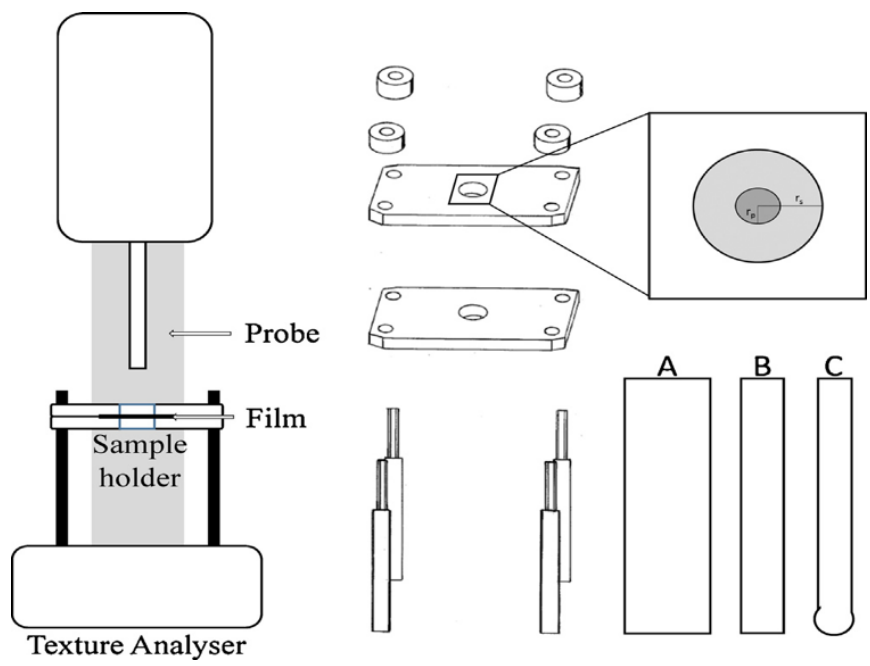

Figure 2. Experimental setup for ODF puncture test (left) and sample holder for film preparations [36].
Results obtained from these measurements can be used to calculate elongation to puncture $(\varepsilon p)$, puncture strength (PS) and the energy to puncture per unit volume $(\Delta \mathrm{Ep})$ according to equations 4-6 [24]:

$$
\varepsilon p \frac{\sqrt{r^{2}+D^{2}}-r}{r} \times 100
$$

where:

$\mathrm{r}=$ radius of the ODF located in the cavity of the film holder; $\mathrm{D}=$ displacement of the probe from point of contact to point of puncture.

$$
P S=\frac{F_{\text {load }}}{\mathrm{A}}
$$

where:

$\mathrm{F}_{\text {load }}=$ load required to puncture the ODF;

$\mathrm{A}=$ cross-sectional area of the edge of the ODF located in the path of the cylindrical hole of the ODF holder.

$$
\Delta E p=\frac{\mathrm{AUC}}{V}
$$

where:

$\mathrm{V}=$ volume of the ODF located in the cavity of the film holder.

\subsubsection{Flexibility (or folding endurance)}

ODF flexibility test measures the ability to withstand handling without fracture during the formation of the jumbo roll or during the unrolling operation, as well as during the consumption by the patient. It can also relevant for the characterization of extemporaneously prepared ODF where access to heavy-duty equipment for tensile properties measurement is difficult. To assess flexibility, ODF are folded in the center area until breakage or up to a predefined maximum folding time $[31,39]$. Also in this case, there are no references on standard procedures or the minimum folding time acceptable to assume damage-free handling [24]. In general, the film is folded until the formation of cracks [39] or bended over a mandrel for a predetermined number of times and the ODF is considered flexible if no cracks were visible at a $5 \times$ magnification using optical microscopy [40].

\subsubsection{Stickiness}

The stickiness, or tackiness, is related to the immediacy of the bond under low contact pressure between a compact specimen and the surface of another material. Stickiness can affect ODF handling because too sticky ODF can present difficulty detachment from the packaging material and stick to the patient's fingers during administration. It could be defined as quick stick, initial adhesion, or stickiness [41].

ODF stickiness can be evaluated qualitatively and quantitatively by thumb tack test and probe tack test, respectively. First, the thumb can be pressed lightly on a film sample for a short period and, then, quickly withdrawn. By varying the pressure and time of contact and noting the difficulty of pulling the thumb from the film, it is possible to perceive how easily, quickly, and/or strongly the film can form a bond with the thumb [31]. 
The probe tack test measures the force required to separate the test probe tip from ODF with predefined dimension. The test can be performed using texture analyzer testing machine which measure the maximum detachment stress calculated by dividing the maximum detachment force by the probe surface area [30].

Most of the methods reported in this section are thought and developed mainly for industrial purposes and often require specialized expertise and relatively expensive equipment. Nevertheless, folding endurance and thumb tack can be adapted to the requirements of small-scale setting, easily performed by trained pharmacist.

\section{Solid-state characterization}

Methods used for characterization of the drug physical state are generally used also in the field of ODF. Differential scanning calorimetry (DSC) enables to analyze both the melting point and glass transition temperature [42,43]. As DSC analysis can be complicated by the residual water content or the presence of excipients with low decomposition temperature, such as glycerol, these data are often confirmed and/or integrated by X-ray diffraction patterns [44] and attenuated total reflection Fourier transform infrared (ATRFTIR) [42]. The latter can be also used to assess the homogeneity in composition [31] and possible drug-polymer interactions in ODF [19].

Surface morphological analysis by imaging techniques are useful to support solid state data [24]. As an example, in the case of solvent casting, self-aggregation of the drugpolymer matrix may occur during drying because of the convective and intermolecular forces [42]. The resulting 'waved' surface of ODF can be an index of homogeneity, aggregated/scattered drug distribution [19,42]. Additionally, the asymmetrical distribution of crystal seeds, which can be detected by polarized light microscopy, might facilitate uneven drug distribution within the ODF. Also SEM could be used to depict drug crystals or changes during storage on the ODF surface $[43,44]$. Moreover, this microscopy technique can reveal surface characteristics in the physical microstructure due to different manufacturing process of ODF, surface features and hence can be used to support dissolution and disintegration results [45]; scanning crosssectional areas of an ODF, it is also possible to visualize the inner inter-connections between multilayer composites.

\section{Uniformity of drug content}

The drug content in ODF are generally quantified by standard drug assay methods. Limits of content uniformity range between 85 and $115 \%$ according to European Pharmacopeias [2]. However, the test for uniformity of dosage units [46] is considered to be among the most appropriate for validating dose uniformity of a manufactured batch of ODF (24) on 10 individual ODF with a single dose. The uniformity of dosage units is assessed by calculating the acceptance value (AV) according to equation 7 :

$A V=M-\bar{x}+k s$

where

$\mathrm{M}=$ the reference value, which depends on the target drug content, $\overline{\mathrm{x}}=$ the mean of individual determined contents, expressed as percent of the label claim,

$k=$ the acceptability constant that varies depending on dosage units $(2.4$ for $\mathrm{n}=10 ; 2.0$ for $\mathrm{n}=30$ )

$s=$ the standard deviation [47].

In most cases, high-performance liquid chromatography (HPLC) is usually used for the determination of drug content in the final dosage form. Nevertheless, the need to implement such assay also to control the process during the continuous manufacturing has been driving the development of nondestructive techniques. As summarized in Table 1, portable handheld near infrared (NIR) spectrometer, calorimeter, and Raman spectrophotometer can allow to identify and quantify API, limiting the use of elaborate and time-consuming analytical techniques. This would also complement and consolidate the using ODF in personalized pharmacotherapy [8].

\section{Disintegration test}

To date, the European Pharmacopoeia only requires that ODF 'disperse rapidly', but detailed information is not available on the acceptable maximum time both in vitro and in vivo [52]. To fill this gap, reference on the ODF disintegration time is being made with respect to orodispersible tablets using water or $\mathrm{pH} 6.8$ phosphate buffer as disintegration medium [3]. Literature data also suggest the use of "simulated-saliva fluids", but again media differing in quali-quantitative composition are reported. As no compendial methods is specified, several set-up have been emerging to take into consideration some peculiarities of ODF with respect to ODT such as variation in the ODF dimensions, simulating the physiological condition in the mouth, mechanical stress of the tongue and most importantly to improve precision in the endpoint detection. From this list reported in Table 2, it is clear the main limitation of the proposed methods is the clear determination of endpoints.

\section{In-vitro dissolution}

$\mathrm{Ph}$. Eur. states that a suitable test should be carried out to demonstrate the appropriate release of the active substance(s) and reference is given to the dissolution test for the conventional solid dosage forms [60]. Also, in this case, methods adapted for solid dosage forms cannot be appropriate for ODF because placing ODF in the vessel, without any sample holding accessory, might lead to poor reproducibility of results: ODF can easily float, stick on the paddle or vessel. Similar issues might arise using basket set-up, flow-through system, or sinkers [24]. Regarding apparatus, the paddle apparatus (USP type II) is more used than the basket apparatus (USP type I) even if modifications, e.g. reduced volume of the dissolution medium or vessel shape, have been introduced. [33], as summarized in Table 3.

Generally speaking, operative conditions should be reproducible, representative, and, possibly, well suited to predict the in vivo performance. To pursue these aims, the physiological condition and mechanical forces in the oral cavity need to be taken into consideration, particularly the invivo small volume of the saliva and the short residence time of ODF in the mouth. 


\begin{tabular}{|c|c|c|c|c|c|c|}
\hline Method & Description & $\begin{array}{lll}\text { Drug(s) } & \text { tested } & \text { and } \\
\text { strength } & & \end{array}$ & Excipients & Application & Comments & Reference \\
\hline $\begin{array}{l}\text { Handheld NIR } \\
\text { spectroscopy } \\
\text { (MicroNIRTMPro } \\
\text { 1700 ES Spectrometer) }\end{array}$ & $\begin{array}{l}\text { The Mini NIR is a portable } \\
\text { compact and lightweight with an } \\
\text { overtone NIR spectral region of } \\
950-1650 \mathrm{~nm} \text {. A transflectance } \\
\text { measuring geometry was used by } \\
\text { applying black surface. The } \\
\text { model was first validated using } \\
\text { chemometrics. }\end{array}$ & $\begin{array}{l}\text { Ondansetron } \\
\text { Chlorpheniramine maleate, } \\
\text { Indomethacin, } \\
\text { Nitrofurantoin, } \\
\text { Dexamethasone each at } \\
\text { doses of } 1,2,3,4,5,6,8 \text {, } \\
\text { and } 10 \mathrm{mg} \text {. }\end{array}$ & $\begin{array}{l}\text { HPMC and } \\
\text { glycerol }\end{array}$ & $\begin{array}{l}\text { Extemporaneous ODF } \\
\text { made by combined } \\
\text { solvent casting and unit- } \\
\text { dose plate }\end{array}$ & $\begin{array}{l}\text { Small size, portability, simple } \\
\text { user interface, rapid } \\
\text { measurement, and real-time } \\
\text { prediction results. Applicable } \\
\text { to individual ODF to enhance } \\
\text { patient safety. }\end{array}$ & [48] \\
\hline 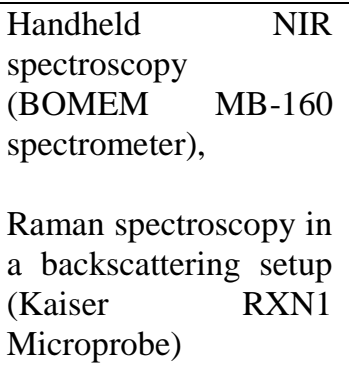 & $\begin{array}{l}\text { Multivariate data analysis was } \\
\text { performed using MatLab } \\
\text { R2015a and PLS Toolbox } 8.0 .1 \\
\text { for the NIR and Raman } \\
\text { respectively to identify and } \\
\text { quantify the active ingredient. }\end{array}$ & $\begin{array}{l}\text { Haloperidol, propranolol } \\
\text { hydrochloride } \\
\text { and montelukast sodium at } \\
\text { dose ranges between } 0.6- \\
12.6 \mathrm{mg}\end{array}$ & $\begin{array}{l}\text { HPMC, } \\
\text { macrogol 4000, } \\
\text { glycerol, } \\
\text { polysorbate } 20, \\
\text { and poloxamer } \\
188 .\end{array}$ & $\begin{array}{l}\text { Inject printed ODF on } \\
\text { HPMC substrate }\end{array}$ & $\begin{array}{l}\text { Valuable, non-destructive, } \\
\text { fast and complementary tool } \\
\text { for quantification inkjet- } \\
\text { printed drug(s). }\end{array}$ & [49] \\
\hline $\begin{array}{lr}\text { Calorimetry (CLM-194 } \\
\text { digital } & \text { handheld } \\
\text { colorimeter) } & \end{array}$ & $\begin{array}{l}\text { Samples were studied on } \\
\text { reflective measurement mode } \\
\text { under the same condition for all } \\
\text { measurements }(\mathrm{n}=3) \text {. } \\
\text { Each color is described by three } \\
\text { numerical values of luminance } \\
\text { and two chromatic components } \\
\text { representing the shift from green } \\
\text { to red and from blue to yellow, } \\
\text { respectively. The color } \\
\text { difference parameters were } \\
\text { subsequently calculated by the } \\
\text { CLM-194 Interface software in } \\
\text { Cartesian coordinates. }\end{array}$ & $\begin{array}{l}\text { propranolol hydrochloride } \\
\text { at a dose of } 0.1-3.2 \mathrm{mg}\end{array}$ & $\begin{array}{l}\text { Water, glycerol, } \\
\text { red edible ink }\end{array}$ & $\begin{array}{l}\text { Inkjet-printed ODF on } 3 \\
\text { substrates, namely: } \\
\text { edible rice paper, edible } \\
\text { icing sheet, and coated } \\
\text { edible rice paper }\end{array}$ & $\begin{array}{l}\text { reliable method to distinguish } \\
\text { the small color differences } \\
\text { between formulations } \\
\text { containing an escalating dose } \\
\text { of propranolol hydrochloride. }\end{array}$ & {$[50]$} \\
\hline $\begin{array}{l}\text { Handheld Raman } \\
\text { spectrophotometer }\end{array}$ & $\begin{array}{l}\text { For each formulation, the } \\
\text { influence of the sampling is } \\
\text { evaluated by acquiring } 3 \text { spots at }\end{array}$ & $\begin{array}{l}\text { Paracetamol, Ibuprofen, } \\
\text { Tramadol, } \\
\text { Pseudoephedrine }\end{array}$ & $\begin{array}{l}\text { MCC, mannitol, } \\
\text { magnesium } \\
\text { stearate, lactose. }\end{array}$ & \begin{tabular}{lc} 
Compressed & \multicolumn{2}{c}{ Tablets. } \\
Application can be \\
extended to continuous
\end{tabular} & $\begin{array}{l}\text { Enhanced the } \\
\text { representativeness of the } \\
\text { sampling. Useful for single or }\end{array}$ & [51] \\
\hline
\end{tabular}



dosage form. The 3 spots were averaged to get a unique

\begin{tabular}{|c|c|}
\hline $\begin{array}{l}\text { chlorhydrate, Caffeine, } \\
\text { triprolidine at dose range of } \\
37.5-1000 \mathrm{mg}\end{array}$ & $\begin{array}{l}\text { manufacturing } \\
\text { compounded ODF. }\end{array}$ \\
\hline
\end{tabular}

or fixed-dose combination of spectrum. Data processing and

validation were performed using Matlab R2018b, and multivariate analysis. 
Table 2. Summary of modified methods to test ODF disintegration. All tests were carried out at $37^{\circ} \mathrm{C}$.

(1)

\begin{tabular}{|c|c|c|c|c|}
\hline Method & Medium and test condition & Endpoint detection & Comment & Reference \\
\hline Petri dish & $10 \mathrm{~mL}$ distilled water & Time for ODF break & $\begin{array}{l}\text { Visual observation may not be } \\
\text { accurate, and breaking only may not } \\
\text { justify disintegration }\end{array}$ & [53] \\
\hline $\begin{array}{l}\text { Modified } \\
\text { disintegration } \\
\text { apparatus with a } \\
\text { vertical ODF clip }\end{array}$ & $\begin{array}{l}\text { Purified water with ODF moving vertically at } 30 \\
\text { stroke/ min }\end{array}$ & $\begin{array}{l}\text { Time require for the ODF to } \\
\text { disintegrate }\end{array}$ & $\begin{array}{l}\text { The method can eliminate the } \\
\text { tendency of ODF sticking to the } \\
\text { vessel wall }\end{array}$ & {$[54]$} \\
\hline $\begin{array}{l}\text { Thermomechanical } \\
\text { analysis }\end{array}$ & $\begin{array}{l}\text { Purified water } 250 \mu \mathrm{L} \text { drop after annealing ODF } \\
\text { coated in a crucible dis with } 900 \mu \mathrm{m} \text { width. } \\
\text { Measuring sensor is attached with a constant force } \\
\text { of } 0.02 \mathrm{~N}\end{array}$ & $\begin{array}{l}\text { The swelling of the film is measure } \\
\text { using thermomechanically as reference } \\
\text { for ODF disintegration. }\end{array}$ & $\begin{array}{l}\text { It may not be suitable for non- } \\
\text { swellable film-forming materials. }\end{array}$ & {$[55]$} \\
\hline $\begin{array}{l}\text { Disintegration test } \\
\text { system with electronic } \\
\text { end-point detection }\end{array}$ & $\begin{array}{l}\text { Water, pH } 6.0 \text { phosphate buffer, and simulated } \\
\text { salivary fluid. Top and bottom ODF clamp with a } 3 \\
\text { g weight attached to the bottom clamp connected to } \\
\text { a brass conductor which when released with ODF } \\
\text { piece during disintegration sends a signal to the } \\
\text { analyzer }\end{array}$ & $\begin{array}{l}\text { Disintegration time recorded } \\
\text { electronically from the analyzer }\end{array}$ & $\begin{array}{l}\text { The method mimics the human tongue } \\
\text { when licking coupled with automatic } \\
\text { electronic end-point detection could } \\
\text { improve extrapolation to humans in } \\
\text { real life. }\end{array}$ & {$[52]$} \\
\hline Slide frame & $\begin{array}{l}700 \mathrm{~mL} \text { Purified water. ODF are clamp in an arm } \\
\text { that moves up and down with a frequency of } 30 \\
\text { cycles/min over a distance of } 55 \mathrm{~mm} \text { horizontally } \\
\text { into the medium. }\end{array}$ & $\begin{array}{l}\text { The time at which complete } \\
\text { disintegration occurs is considered as } \\
\text { the disintegration time assessed by } \\
\text { visual inspection }\end{array}$ & $\begin{array}{l}\text { The method prevents sticking of ODF } \\
\text { on the mesh wall in the conventional } \\
\text { tablets and capsule disintegration } \\
\text { testing unit }\end{array}$ & [56] \\
\hline $\begin{array}{l}\text { Disintegration test unit } \\
\text { (DTU) with a clear } \\
\text { endpoint }\end{array}$ & $\begin{array}{l}\text { ODF holder comprises two L-shaped pieces: a base } \\
\text { piece and a top piece held together by magnets that } \\
\text { are built into each of their vertical plates. The ODF } \\
\text { holders are dip into a disintegration basket from the } \\
\text { top with vessels containing } 700 \mathrm{~mL} \text { of the media. } \\
\text { The DTU moves together with the disintegration } \\
\text { basket during the stroke movements of the test inside } \\
\text { the vessel. The DTU holds the ODFs in a horizontal } \\
\text { position }\end{array}$ & $\begin{array}{l}\text { The disintegration endpoint is defined } \\
\text { as the breaking of the ODF from the } \\
\text { viewing area. The disintegration time } \\
\text { of each sample is automatically } \\
\text { recorded on the built-in timer on the } \\
\text { disintegration apparatus }\end{array}$ & $\begin{array}{l}\text { Suitable for quality control of ODF at } \\
\text { the early stage of development and for } \\
\text { industrial manufacturing with } \\
\text { improved end-point detection and } \\
\text { automatic recording. }\end{array}$ & {$[57]$} \\
\hline $\begin{array}{l}\text { Slide frame and ball } \\
\text { (SFaB) }\end{array}$ & $\begin{array}{l}\text { A stainless-steel ball (diameter } 10 \mathrm{~mm} \text {, and weight } 4 \\
\mathrm{~g} \text { ) is place on top of the ODF which simulates the } \\
\text { mechanical stress of the tongue to break through the } \\
\text { wetted ODF with } 900 \mu \mathrm{L} \text { physiological media and } \\
\text { dropped on the bottom of the disintegration unit. The }\end{array}$ & $\begin{array}{l}\text { Endpoint indicates the time needed for } \\
\text { the stainless-steel ball to break through } \\
\text { the wetted ODF and fall down the unit. }\end{array}$ & $\begin{array}{l}\text { The clear endpoint enables the } \\
\text { simulation of physiological } \\
\text { conditions in the oral cavity, and } \\
\text { mimic the mechanical force of the } \\
\text { tongue. Suitable for research and } \\
\text { development of ODF. However, it }\end{array}$ & {$[58,59]$} \\
\hline
\end{tabular}


PharmaTest ${ }^{\circledR}$ film

disintegration tester total area of the ODF to be exposed for the test is $2 \times 3$ $\mathrm{cm}$

It is a modified form of pharmacopeial disintegration

test set up for tablets and capsules equipped with six

sample holders for ODF with an integrated clamping

device. Mass ( $3 \mathrm{~g}$ ) are fixed to the lower end of each

ODF along with the lower clamp which simulates

the applied mechanical stress of the tongue. Each

ODF is housed in its transparent glass tube. The

whole unit is immersed in the testing vessel filled

with $900 \mathrm{~mL}$ media. Each clamp moves 30 strokes

per minute within a distance of $55 \mathrm{~mm}$.

\begin{tabular}{|c|c|c|}
\hline & $\begin{array}{l}\text { does not consider the disintegration of } \\
\text { the whole ODF. }\end{array}$ & \\
\hline $\begin{array}{l}\text { lime taken for the } 3 \mathrm{~g} \text { weight to } \\
\text { op down and close the contact } \\
\text { tween two sieve halves of the } \\
\text { idded floor is measured as the } \\
\text { sintegration endpoint. }\end{array}$ & $\begin{array}{l}\text { Able to mimic the mechanical forces } \\
\text { in the tongue, use of physiological } \\
\text { media and the automatic endpoint } \\
\text { detection. } \\
\text { Applicable for industrial } \\
\text { manufacturing quality control of } \\
\text { ODF. }\end{array}$ & [58] \\
\hline
\end{tabular}


As ODF usually exhibit a rapid dissolution, online UVspectrometry fiber optic sensor systems [3] are gaining increasing interest to provide a reliable dissolution profiles overcoming the difficulties related to conventional sampling procedures (Table 3).

\section{Evaluation of shelf-life}

The stability of ODF must be evaluated according to the International Conference on Harmonization (ICH) guidelines for oral dosage forms. In long term, intermediate or accelerated stability studies, ODF properties evaluated over time are related to their critical quality attributes usually mechanical properties, disintegration and dissolution. All these aspects can be affected by ageing but also by variation of humidity.

Thus, the packaging of the films plays an important role to ensure that ODF maintain their quality attributes over time, e.g. drug content and dissolution rate [69]. Furthermore, as ODF are highly sensitive to humid conditions, moisture uptake should be also monitored [70]. Air-tight primary packaging materials, such as aluminum sachets, are often necessary to preserve ODF feature over time [71] despite the high costs. Foil, paper or plastic pouches can be considered as secondary packaging material. Though, their suitability needs to be carefully evaluated for a specific formulation including aspects of ODF stability and packaging materials suitability for pharmaceuticals [11].

\section{In vitro biopharmaceutical evaluation}

ODF are designed to cause the release drug substances therein for either systemic or a local effect. For local treatment, absorption of the API is not desired, as side effects may occur. When a systemic effect is required, the API can either be swallowed and absorbed via the gastrointestinal tract or be absorbed via the oromucosal membrane. Absorption through the oromucosal membrane may increase the bioavailability compared to conventional oral solid dosage forms when the API is affected by significant first-pass metabolism [2]. Such an improvement of the bioavailability may be advantageous for new ODF products but may also cause problems related to toxicity if not carefully studied prior to clinical application. Controlled absorption of API from ODF through the oral mucosa can be also achieved by incorporating excipients, e.g. ion exchange resins, or complementary process, e.g. particle coating techniques $[11,72,73]$. Therefore, regardless the approach followed, absorption through the oral mucosa should also be investigated using both in vitro or in vivo permeation studies. As an example, ex vivo permeation study of iloperidone loaded in ODF was carried out using porcine tissue on Franz diffusion cell in $\mathrm{pH} 6.8$ phosphate buffer [74]. Similarly, Santi et al., investigated the permeation of lidocaine using esophageal isolated epithelium in $\mathrm{pH} 7.4$ phosphate buffer
[75]. Pharmacokinetics studies comparing the plasma concentration curves of API loaded in ODF and other conventional solid dosage forms available in the market can permit to assess when a dose adjustment is required in ODF formulations. These studies can as well be achieved using human volunteers [70,76], and/or animal models $[61,74]$.

\section{CONCLUSIONS}

ODF have been attracting more attention among researchers and pharmaceutical industries as innovative dosage forms able to solve some of the peculiar problems of convention solid and liquid dosage forms. In recent years, ODF are a fastest growing part of personalized medicine focusing more on precision dosing. Therefore, advancement in the characterization technologies needs to evolve to evaluate their specific attributes. What is left is for the regulatory authorities to step out and harmonize means of quality standards for ODF evaluation as currently, they are very scanty and not well explicit where they exist.

Moreover, for ODF extemporaneously prepared in small batches for personalized therapy, less complex, easy to use and non-destructive assays need to be optimized. Along with methods to quantify the drug contents and uniformity, mechanical properties are of vital importance. Tackiness (thumb tack test), and folding endurance could be easily evaluated to guarantee the mechanical quality of ODF prepared on demand. These tests do not need any intensive equipment and they can be easily conducted by a well-trained pharmacist.

\section{CONFLICT OF INTEREST}

Non to declare.

\section{FUNDING}

Non to declare.

\section{ACKNOWLEDGEMENTS}

Non to declare. 
Table 3. Modified in vitro dissolution methods for ODF. All experiments were carried out at $37 \pm 0.5^{\circ} \mathrm{C}$.

\begin{tabular}{|c|c|c|c|c|c|c|}
\hline Dissolution method & $\begin{array}{l}\text { Media volume and } \\
\text { composition }\end{array}$ & $\begin{array}{l}\text { Stirring } \\
\text { rate }\end{array}$ & Sampling & $\begin{array}{l}\text { Analytical } \\
\text { method }\end{array}$ & Special features & Reference \\
\hline JP15 paddle apparatus & $\begin{array}{l}900 \mathrm{~mL} \text { of } \mathrm{pH} 1.2 \\
\text { phosphate buffer }\end{array}$ & $50 \mathrm{rpm}$ & $\begin{array}{l}10 \mathrm{~mL} 2 \mathrm{~min} \text { for } 120 \\
\min \end{array}$ & HPLC & & [61] \\
\hline $\begin{array}{l}\text { Ph.Eur. basket dissolution } \\
\text { apparatus }\end{array}$ & $\begin{array}{l}500 \mathrm{~mL} \text { freshly deionized } \\
\text { water }\end{array}$ & $25 \mathrm{rpm}$ & $3 \mathrm{~min}$ & $\begin{array}{l}\text { UV-Vis } \\
\text { spectroscopy }\end{array}$ & & [23] \\
\hline $\begin{array}{l}\text { Ph. Eur. paddle } \\
\text { dissolution apparatus }\end{array}$ & $\begin{array}{l}500 \mathrm{~mL} \text { vessel filled with } \\
400 \mathrm{~g} \text { of degassed } \mathrm{pH} 7.4 \\
\text { sodium phosphate buffer }\end{array}$ & $50 \mathrm{rpm}$ & Automated & $\begin{array}{l}\text { UV-fiber } \\
\text { optical probe }\end{array}$ & $\begin{array}{l}\text { Inline detecting points each second by } \\
\text { UV-fiber optical probe immersed into the } \\
\text { dissolution medium. } \\
\text { 'One Chamber Method' to detect drug } \\
\text { dissolution and the concentration in the } \\
\text { same chamber, using the complete } 400 \mathrm{~g} \\
\text { fluid as dissolution medium. } \\
\text { 'Punch \& Filter Method' which mimic the } \\
\text { conditions in the oral cavity was also } \\
\text { incorporated. }\end{array}$ & {$[62]$} \\
\hline Beaker Stirring Method & $\begin{array}{l}150 \mathrm{~mL} \text { pH } 6.8 \text { simulated } \\
\text { saliva and pH } 1.3, \\
\text { artificial gastric media }\end{array}$ & $200 \mathrm{rpm}$ & $\begin{array}{l}1 \mathrm{~mL} \text { every } 30 \\
\text { seconds in the first } 5 \\
\text { min, then at } 15,30, \\
60 \text { and } 120 \mathrm{~min}\end{array}$ & $\begin{array}{l}\text { UV } \\
\text { spectroscopy }\end{array}$ & $\begin{array}{l}\text { Two different media were employed to } \\
\text { simulate the conditions in the oral cavity } \\
\text { and in the stomach. } \\
\text { Beaker was used as the dissolution vessel } \\
\text { under magnetic stirrer. }\end{array}$ & {$[63,64]$} \\
\hline $\begin{array}{l}\text { USP dissolution } \\
\text { apparatus I }\end{array}$ & $\begin{array}{l}900 \mathrm{~mL} \text { pH } 6.8 \text { phosphate } \\
\text { buffer }\end{array}$ & $100 \mathrm{rpm}$ & $\begin{array}{l}5,10, \text { and } \\
30 \mathrm{~min}\end{array}$ & $\begin{array}{l}\text { HPLC-UV } \\
\text { system }\end{array}$ & & [4] \\
\hline USP type II apparatus & $\begin{array}{l}50 \mathrm{~mL} \text { pH } 6 \\
\text { phosphate buffer }\end{array}$ & $50 \mathrm{rpm}$ & $1 \mathrm{~mL}$ & HPLC & $\begin{array}{l}\text { The withdrawn samples were centrifuged } \\
\text { at } 15.000 \mathrm{rpm} \text { at } 20{ }^{\circ} \mathrm{C} \text { for } 10 \mathrm{~min} \text {, to } \\
\text { remove residual particles. }\end{array}$ & {$[65]$} \\
\hline $\begin{array}{l}\text { Modified petri dish } \\
\text { approach (closed } \\
\text { cylindrical glass vial } \\
\text { housed in a thermostat } \\
\text { shaking water bath) }\end{array}$ & $\begin{array}{l}5 \mathrm{~mL} \text { of } \mathrm{pH} 6.8 \text { simulated } \\
\text { saliva pre-heated }\end{array}$ & $10 \mathrm{rpm}$ & $\begin{array}{l}5 \mathrm{~mL} \text { (as a whole in } \\
\text { triplicates) }\end{array}$ & $\begin{array}{l}\text { UV-Vis } \\
\text { spectroscopy }\end{array}$ & $\begin{array}{l}\text { The modified petri dish was coupled with } \\
\text { a digital stopwatch. } \\
\text { Changes in test sample physical forms } \\
\text { were viewed under a white fluorescent } \\
\text { light to enhance visibility } \\
\text { Dissolution time represented the period } \\
\text { required for each strip to undergo } \\
\text { complete solvation/dissolution into a } \\
\text { homogenous solution. }\end{array}$ & {$[66,67]$} \\
\hline
\end{tabular}


Principle Authoret al.

\begin{tabular}{|c|c|c|c|c|c|c|}
\hline & & & & & $\begin{array}{l}\text { The } \mathrm{pH} \text { of the final solution was also } \\
\text { tested. }\end{array}$ & \\
\hline $\begin{array}{l}\text { Ph. Eur. paddle } \\
\text { dissolution apparatus }\end{array}$ & $\begin{array}{l}900 \mathrm{~mL} \text { freshly deionized } \\
\text { water and } \mathrm{pH} 5.7 \text { artificial } \\
\text { saliva }\end{array}$ & $50 \mathrm{rpm}$ & & $\begin{array}{l}\text { UV-Vis } \\
\text { spectroscopy }\end{array}$ & Two different media were used. & {$[31]$} \\
\hline $\begin{array}{l}\text { Ph. Eur. basket } \\
\text { dissolution apparatus }\end{array}$ & $\begin{array}{l}900 \mathrm{~mL} \text { freshly deionized } \\
\text { water, } \\
\text { maintained }\end{array}$ & $50 \mathrm{rpm}$ & 2 min intervals & $\begin{array}{l}\text { UV-Vis } \\
\text { spectroscopy }\end{array}$ & & [5] \\
\hline $\begin{array}{l}\text { USP type-IV (flow- } \\
\text { through cell) combined } \\
\text { with paddle apparatus } \\
\text { (USP } \\
\text { type II). }\end{array}$ & $\begin{array}{l}\text { Artificial saliva, artificial } \\
\text { gastric fluid, artificial } \\
\text { intestine fluid, pH } 6.6 \\
\text { phosphate buffer } 16.2 \pm \\
0.06 \mathrm{~mL}\end{array}$ & $50 \mathrm{rpm}$ & $\begin{array}{l}60 \mathrm{~s} \text { for } \\
1000 \mathrm{~min} \text { (online } \\
\text { automated) }\end{array}$ & $\begin{array}{l}\text { UV-Vis } \\
\text { spectroscopy }\end{array}$ & $\begin{array}{l}\text { The system was operated in closed-loop by } \\
\text { means of a peristaltic pump. } \\
\text { In-house sample holder FH3D }(22.6 \mathrm{~mm}) \\
\text { held the ODF with adhesive tape which } \\
\text { prevent floating, sticking together, and } \\
\text { adherence of the ODF to the chamber wall. } \\
\text { Four different media were used. }\end{array}$ & {$[68]$} \\
\hline
\end{tabular}




\section{REFERENCES}

[1] Badgujar, B.P.; Mundada, A.S. The technologies used for developing orally disintegrating tablets: A review. Acta Pharm. 2011, 61(2), 117-39.

[2] Dixit, R.P.; Puthli, S.P. Oral strip technology: Overview and future potential. $J$ Control Release. 2009, 139(2), 94-107.

[3] Cilurzo, F.; Musazzi, U.M.; Franzé, S.; Selmin, F.; Minghetti, P. Orodispersible dosage forms: biopharmaceutical improvements and regulatory requirements. Drug Discov Today. 2018, 23(2), 2519. http://dx.doi.org/10.1016/j.drudis.2017.10.003

[4] Pimparade, M.B.; Vo, A.; Maurya, A.S.; Bae, J.; Morott, J.T.; Feng, X.; Kim, D.W.; Kulkarni, V.I.; Tiwari, R.; Vanaja, K.; Murthy, R.; Shivakumar, H.N.; Neupane, D.; Mishra, S.R.; Murthy, S.N. Repka, M.A. Development and Evaluation of an Oral Fast Disintegrating Anti-allergic Film Using Hot-melt Extrusion Technology. Eur J Pharm Biopharm. 2017, 119 , $81-90$. http://dx.doi.org/10.1016/j.ejpb.2017.06.004

[5] Musazzi, U.M.; Selmin, F.; Ortenzi. M.A.; Khalid, G.M.; Franzé, S.; Minghetti, P.; Cilurzo, F. Personalized orodispersible films by hot melt ram extrusion 3D printing. Int J Pharm. 2018, 551, 52-59. https://doi.org/10.1016/j.ijpharm.2018.09.013

[6] Lai, F.; Franceschini, I.; Corrias, F.; Sala, M.C.; Cilurzo, F.; Sinico, C.; Pini, E. Maltodextrin fast dissolving films for quercetin nanocrystal delivery. A feasibility study. Carbohydr. Polym. 2015, 121, 217223. https://doi.org/10.1016/j.carbpol.2014.11.070

[7] Musazzi, U.M.; Passerini, N.; Albertini, B.; Dolci, L.S.; Cilurzo, F. A new melatonin oral delivery platform based on orodispersible films containing solid lipid microparticles. Int. J. Pharm. 2019, 559, 280 288. https://doi.org/10.1016/j.ijpharm.2019.01.046

[8] Musazzi, U.M.; Khalid, G.M.; Selmin, F.; Minghetti, P.; Cilurzo, F. Trends in the production methods of orodispersible films. Int J Pharm. 2020, 576, 118963. https://doi.org/10.1016/j.ijpharm.2018.09.013

[9] Amelian, A.; Wasilewska, K.; Wesoły, M.; CiosekSkibińska, P.; Winnicka, K. Taste-masking assessment of orally disintegrating tablets and lyophilisates with cetirizine dihydrochloride microparticles. Saudi Pharm J. 2017, 25(8), 1144-50.

[10] Borges, A.F.; Silva, C.; Coelho, J.F.J.; Simões, S. Outlining critical quality attributes (CQAs) as guidance for the development of orodispersible films. Pharm Dev Technol. 2017, 22(2), 237-45.

[11] Krampe, R.; Visser, J.C.; Frijlink, H.W.; Breitkreutz, J.; Woerdenbag, H.J.; Preis, M. Oromucosal film preparations: points to consider for patient centricity and manufacturing processes. Expert Opin Drug Deliv. 2016, 13(4), 493-506. http://www.tandfonline.com/doi/full/10.1517/174252 47.2016.1118048

[12] Kianfar, F.; Chowdhry, B.Z.; Antonijevic, M.D.; Boateng, J.S. Novel films for drug delivery via the buccal mucosa using model soluble and insoluble drugs. Drug Dev Ind Pharm. 2012, 38(10), 1207-20.

[13] Das, N.G.; Das, S.K. Development of Mucoadhesive Dosage Forms of Buprenorphine for Sublingual Drug Delivery. Drug Deliv J Deliv Target Ther Agents. 2004, 11(2), 89-95.

[14] Woertz, C.; Kleinebudde, P. Development of orodispersible polymer films with focus on the solid state characterization of crystalline loperamide. Eur $J$ Pharm Biopharm. 2015, 94, 52-63. http://dx.doi.org/10.1016/j.ejpb.2015.04.036

[15] Vuddanda, P.R.; Montenegro-Nicolini, M.; Morales, J.O.; Velaga, S. Effect of surfactants and drug load on physico-mechanical and dissolution properties of nanocrystalline tadalafil-loaded oral films. Eur $J$ Pharm Sci. 2017, 109, 372-80. https://doi.org/10.1016/j.ejps.2017.08.019

[16] Içten, E.; Giridhar, A.; Taylor, L.S.; Nagy, Z.K.; Reklaitis, G.V. Dropwise additive manufacturing of pharmaceutical products for melt-based dosage forms. J Pharm Sci. 2015, 104(5), 1641-9.

[17] Azizi, M.S.; Mohaved, S.; Narayan, R.J. Inkjet dispensing technologies: recent advances for novel drug discovery. Expert Opin Drug Discov. 2019, 14(2),101-113. https://doi.org/10.1080/17460441.2019.1567489

[18] Alomari, M.; Mohamed, F.H.; Basit, A.W.; Gaisford, S. Personalised dosing: Printing a dose of one's own medicine. Int $J$ Pharm. 2015, 494(2), 568-77. http://dx.doi.org/10.1016/j.ijpharm.2014.12.006

[19] Nair, A.B.; Kumria, R.; Harsha, S.; Attimarad, M.; Al-Dhubiab, B.E.; Alhaider, I.A. In vitro techniques to evaluate buccal films. J Control Release. 2013, 166(1),10-21.

[20] Patel, V.M.; Prajapati, B.G.; Patel, M.M. Effect of Hydrophobic Polymers on Buccoadhesive Eudragit Patches of Propanolol Hydrochloride Using Factorial Design. AAPS PharmSciTech. 2007, 8(2), E1-8.

[21] Cao, N.; Yang, X.; Fu, Y. Effects of various plasticizers on mechanical and water vapor barrier properties of gelatin films. Food Hydrocoll. 2009, 23(3),729-35.

http://dx.doi.org/10.1016/j.foodhyd.2008.07.017

[22] Niese, S.; Quodbach, J. Application of a chromatic confocal measurement system as new approach for inline wet film thickness determination in continuous oral film manufacturing processes. Int J Pharm. 2018 , 
551(1-2), 203-11.

[23] Cilurzo, F.; Cupone, I.E.; Minghetti, P.; Buratti, S.; Gennari, C.G.M.; Montanari, L. Diclofenac fastdissolving film: Suppression of bitterness by a tastesensing system. Drug Dev Ind Pharm. 2011, 37(3), 252-9.

[24] Preis, M.; Woertz, C.; Kleinebudde, P.; Breitkreutz, J. Oromucosal film preparations: classification and characterization methods. Expert Opin Drug Deliv. 2013,10(9),1303-17.

http://www.tandfonline.com/doi/full/10.1517/174252 47.2013.804058

[25] Miyanaga, Y.; Tanigake, A.; Nakamura, T.; Kobayashi, Y.; Ikezaki, H.; Taniguchi, A.; Matsuyama, K.; Uchida T. Prediction of the bitterness of single, binary- and multiple-component amino acid solutions using a taste sensor. Int J Pharm. 2002, 248(1-2), 207-18.

[26] Haraguchi, T.; Yoshida, M.; Kojima, H.; Uchida, T. Usefulness and limitations of taste sensors in the evaluation of palatability and taste-masking in oral dosage forms. Asian J Pharm Sci. 2016, 11(4), 47985. http://dx.doi.org/10.1016/j.ajps.2016.03.001

[27] Haraguchi, T.; Yoshida, M.; Uchida, T. Evaluation of ebastine-loaded orally disintegrating tablets using new apparatus of detecting disintegration time and etongue system. J Drug Deliv Sci Technol. 2014, 24(6), 684-8.http://dx.doi.org/10.1016/S1773-

2247(14)50137-2

[28] Nakamura, H.; Uchida, S.; Sugiura, T.; Namiki, N. The prediction of the palatability of orally disintegrating tablets by an electronic gustatory system. Int $J$ Pharm. 2015, 493(1-2), 305-12. http://dx.doi.org/10.1016/j.ijpharm.2015.07.056

[29] Al-Kasmi, B.; Al-Rahal, O.; El-Zein, H.; Nattouf, A.H. Structural and in vitro in vivo evaluation for taste masking. Expert Opin. Drug Deliv. 2018, 15(11), 1105-1116.

[30] Khadra, I.; Obeid, M.A.; Dunn, C.; Watts, S.; Halbert, G.; Ford, S.; Mullen A. Characterisation and optimisation of diclofenac sodium orodispersible thin film formulation. Int J Pharm. 2019, 561:43-6. https://linkinghub.elsevier.com/retrieve/pii/S037851 731930105X

[31] Musazzi, U.M.; Selmin, F.; Franzé, S.; Gennari, C.G.M.; Rocco, P.; Minghetti, P.; Cilurzo F. Poly(methyl methacrylate) salt as film forming material to design orodispersible films. Eur J Pharm Sci. 2018, 115, 37-42. https://doi.org/10.1016/j.ejps.2018.01.019

[32] Lal, M.; Lai, M.; Estrada, M.; Zhu, C.; Developing a Flexible Pediatric Dosage Form for Antiretroviral Therapy: A Fast-Dissolving Tablet. J Pharm Sci. 2017, 106(8), 2173-7. http://dx.doi.org/10.1016/j.xphs.2017.05.004

[33] Borges, A.F.; Silva, C.; Coelho,; J.F.J.; Simões, S. Oral films: Current status and future perspectives: IGalenical development and quality attributes. $J$ Control Release. 2015, 206, 1-19. http://dx.doi.org/10.1016/j.jconrel.2015.03.006

Boateng, J.S.; Auffret, A.D.; Matthews, K.H.; Humphrey, M.J.; Stevens, H.N.E.; Eccleston, G.M. Characterisation of freeze-dried wafers and solvent evaporated films as potential drug delivery systems to mucosal surfaces. Int J Pharm. 2010, 389(1-2), 2431. http://dx.doi.org/10.1016/j.ijpharm.2010.01.008

[35] European Pharmacopoeia Commission. Oromucosal Preparations. In: European Pharmacopoeia. 8th ed. Strasbourg: European Directorate for the Quality of Medicines (EDQM); 2014.

[36] Preis, M.; Knop, K.; Breitkreut, J. Mechanical strength test for orodispersible and buccal films. Int $\mathrm{J}$ Pharm. 2014, 461(1-2), 22-29. http://dx.doi.org/10.1016/j.ijpharm.2013.11.033

[37] Franceschini, I.; Selmin, F.; Pagani, S.; Minghetti, P.; Cilurzo, F. Nanofiller for the mechanical reinforcement of maltodextrins orodispersible films. Carbohydr. Polym., 2016, 136, 676-681.

[38] Radebaugh, G.W.; Murtha, J.L.; Julian, T.N.; Bondi, J.N. Methods for evaluating the puncture and shear properties of pharmaceutical polymeric films. Int $J$ Pharm. 1988, 45(1-2), 39-46.

[39] Puratchikody, A.; Prasanth, V.V.; Mathew, S.T.; Kumar, B.A. Development and characterization of mucoadhesive patches of salbutamol sulfate for unidirectional buccal drug delivery. Acta Pharm. 2011, 61(2), 157-70.

[40] Cilurzo, F.; Cupone, I.E.; Minghetti, P.; Selmin, F.; Montanari, L. Fast dissolving films made of maltodextrins. Eur. J. Pharm. Biopharm. 2008, 70(3), 895-900.

[41] Minghetti, P.; Cilurzo, F.; Casiraghi, A. Measuring adhesive performance in transdermal delivery systems. Am J Drug Deliv. 2004, 2(3), 193-206.

[42] Karki, S.; Kim.; H, Na, S.J.; Shin, D.; Jo, K.; Lee, J. Thin films as an emerging platform for drug delivery. Asian J Pharm Sci. 2016, 11(5), 559-74. http://dx.doi.org/10.1016/j.ajps.2016.05.004

[43] Coates, J. Interpretation of Infrared Spectra, A Practical Approach. Encycl Anal Chem. 2006, 1-23. http://doi.wiley.com/10.1002/9780470027318.a5606

[44] Pongjanyakul, T.; Suksri, H. Alginate-magnesium aluminum silicate films for buccal delivery of nicotine. Colloids Surfaces B Biointerfaces. 2009 74(1), 103-113.

[45] Preis, M.; Pein, M.; Breitkreutz, J. Development of a taste-masked orodispersible film containing dimenhydrinate. Pharmaceutics. 2012, 4(4), 551-62.

[46] European Pharmacopoeia Commission. 2.9.40 uniformity of dosage units. In: European Pharmacopoeia. edition 7.0. European Directorate for the Quality of Medicines (EDQM); Strasbourg, France: 2008.

[47] European Pharmacopoeia Commission. Oromucosal Preparations. In European Pharmacopoeia. 7.4 edition. European Directorate for the Quality of Medicines (EDQM); Strasbourg, France; 2012. p. 4257-Updated monograph on 'oromucosal 
preparations' by the European Pharmacopoeia.

[48] Foo, W.C.; Widjaja, E.; Khong, Y.M.; Gokhale, R. Chan, S.Y. Application of miniaturized near-infrared spectroscopy for quality control of extemporaneous orodispersible films. J Pharm Biomed Anal. 2018, 150,191-198.

http://dx.doi.org/10.1016/j.jpba.2017.11.068

[49] Edinger, M.; Iftimi, L.D.; Markl, D.; Al-Sharabi, M.; Bar-Shalom, D.; Rantanen, J.; Genina, N. Quantification of Inkjet-Printed Pharmaceuticals on Porous Substrates Using Raman Spectroscopy and Near-Infrared Spectroscopy. AAPS PharmSciTech. 2019, 20, 207.

[50] Vakili, H.; Nyman, J.O.; Genina, N.; Preis, M.; Sandler, N. Application of a colorimetric technique in quality control for printed pediatric orodispersible drug delivery systems containing propranolol hydrochloride. Int J Pharm. 2016, 511(1), 606-18.

[51] Coic, L.; Sacré, P.Y.; Dispas, A.; Dumont, E.; Horne, J.; De Bleye, C.; Fillet, M.; Hubert P.; Ziemons. E. Evaluation of the analytical performances of two Raman handheld spectrophotometers for pharmaceutical solid dosage form quantitation. Talanta. $\quad \mathbf{2 0 2 0}, \quad 214, \quad 120888$. https://doi.org/10.1016/j.talanta.2020.120888

[52] Preis, M.; Gronkowsky, D.; Grytzan, D.; Breitkreutz, J. Comparative study on novel test systems to determine disintegration time of orodispersible films. J Pharm Pharmacol. 2014, 66(8), 1102-11.

[53] El-Setouhy, D.A.; El-Malak, N.S.A. Formulation of a Novel Tianeptine Sodium Orodispersible Film. AAPS PharmSciTech. 2010, 11(3), 1018-25. http://www.springerlink.com/index/10.1208/s12249010-9464-2

[54] Sakuda, Y.; Ito, A.; Sasatsu, M.; Machida, Y. Preparation and evaluation of medicinal carbon oral films. Chem Pharm Bull. 2010, 58(4), 454-7.

[55] Garsuch, V.; Breitkreutz, J. Novel analytical methods for the characterization of oral wafers. Eur J Pharm Biopharm. 2009, 73(1), 195-201. http://dx.doi.org/10.1016/j.ejpb.2009.05.010

[56] Visser, J.C.; Woerdenbag, H.J.; Crediet, S.; Gerrits, E.; Lesschen, M.A.; Hinrichs, W.L.J.; Breitkreutz, J.; Frijlink H.W. Orodispersible films in individualized pharmacotherapy: The development of a formulation for pharmacy preparations. Int J Pharm. 2015, 478(1), 155-63.

http://dx.doi.org/10.1016/j.ijpharm.2014.11.013

[57] Low, A.; Kok, S.L.; Khong, Y.M.; Chan, S.Y.; Gokhale, R. A New Test Unit for Disintegration EndPoint Determination of Orodispersible Films. $J$ Pharm Sci. 2015, 104(11), 3893-903.

[58] Speer, I.; Steiner, D.; Thabet, Y.; Breitkreutz, J.; Kwade, A. Comparative study on disintegration methods for oral film preparations. Eur J Pharm Biopharm. 2018, 132, 50-61.

[59] Steiner, D.; Finke, J.H.; Kwade, A. Efficient production of nanoparticle-loaded orodispersible films by process integration in a stirred media mill. Int
J Pharm. 2016, 511(2), 804-13. http://dx.doi.org/10.1016/j.ijpharm.2016.07.058

[60] Anon, Mucoadhesive preparations monograph. In European Pharmacopoeia. (9.5 edn), Council of Europe Suppl. 9.5. 2018

[61] Nishimura, M.; Matsuura, K.; Tsukioka, T.; Yamashita, H.; Inagaki, N.; Sugiyama, T.; Itoh, Y.. In vitro and in vivo characteristics of prochlorperazine oral disintegrating film. Int J Pharm. 2009, 368(1-2), 98-102.

[62] Krampe, R.; Sieber, D.; Pein-Hackelbusch, M.; Breitkreutz, J. A new biorelevant dissolution method for orodispersible films. Eur J Pharm Biopharm. 2016, 98, 20-5. http://dx.doi.org/10.1016/j.ejpb.2015.10.012

[63] Nalluri, B.N.; Sravani, B.; Anusha, V.S.; Sribramhini, R.; Maheswari, K.M. Development and Evaluation of Mouth Dissolving Films of Sumatriptan Succinate for Better Therapeutic Efficacy. J Appl Pharm Sci. 2013, 3(8), 161-6.

[64] Senta-Loys, Z.; Bourgeois, S.; Pailler-Mattei, C.; Agusti, G.; Briançon, S.; Fessi, H. Formulation of orodispersible films for paediatric therapy: investigation of feasibility and stability for tetrabenazine as drug model. J Pharm Pharmacol. 2017, 69(5), 582-92.

[65] Wimmer-Teubenbacher, M.; Planchette, C.; Pichler, H.; Markl, D.; Hsiao, W.K.; Paudel, A.; Stegemann, S. Pharmaceutical-grade oral films as substrates for printed medicine. Int J Pharm. 2018, 547(1-2), 16980. https://doi.org/10.1016/j.ijpharm.2018.05.041

[66] Adeleke, O.A.; Tsai, P.C.; Karry, K.M.; Monama, N.O.; Michniak-Kohn, B.B. Isoniazid-loaded orodispersible strips: Methodical design, optimization and in vitro-in silico characterization. Int J Pharm. 2018, 547(1-2), 347-59. https://doi.org/10.1016/j.ijpharm.2018.06.004

[67] Garsuch, V.; Breitkreutz, J. Comparative investigations on different polymers for the preparation of fast-dissolving oral films. $J$ Pharm Pharmacol. 2010, 62(4), 539-45. http://doi.wiley.com/10.1211/jpp.62.04.0018

[68] Speer, I.; Preis, M.; Breitkreutz, J. Novel Dissolution Method for Oral Film Preparations with Modified Release Properties. AAPS PharmSciTech. 2019, 20(1), 7. http://link.springer.com/10.1208/s12249018-1255-1

[69] Fahmy, R.H.; Badr-Eldin, S.M. Novel delivery approach for ketotifen fumarate: Dissofilms formulation using 32 experimental design: In vitro/in vivo evaluation. Pharm Dev Technol. 2014, 19(5), 521-30.

[70] ElMeshad, A.N.; El-Hagrasy, A.S. Characterization and Optimization of Orodispersible Mosapride Film Formulations. AAPS PharmSciTech. 2011, 12(4), 1384-92.

[71] Hoffmann, E.M.; Breitenbach, A.; Breitkreutz, J. Advances in orodispersible films for drug delivery. Expert Opin Drug Deliv. 2011, 8(3), 299-316. 
http://www.tandfonline.com/doi/full/10.1517/174252 47.2011.553217

[72] Shang, R.; Liu, C.; Quan, P.; Zhao, H.; Fang, L. Effect of drug-ion exchange resin complex in betahistine hydrochloride orodispersible film on sustained release, taste masking and hygroscopicity reduction. Int. J. Pharm. 2018, 545(1-2), 163-169.

[73] Speer, I.; Lenhart, V.; Preis, M.; Breitkreutz, J. Prolonged release from orodispersible films by incorporation of diclofenac-loaded micropellets. Int. J. Pharm. 2019, 554, 149-160.

[74] Londhe, V.; Shirsat, R. Formulation and Characterization of Fast-Dissolving Sublingual Film of Iloperidone Using Box-Behnken Design for Enhancement of Oral Bioavailability. AAPS PharmSciTech. 2018, 19(3), 1392-400.

[75] Santi, P.; Traversone, V.; Padula, C.; Pozzetti, L.; Nicoli, S. In Vitro Evaluation of Mucoadhesive Films for Gingival Administration of Lidocaine. AAPS PharmSciTech. 2013, 14(4), 1279-83.

[76] Reiner, V.; Giarratana, N.; Monti, N.C.; Breitenbach, A.; Klaffenbach, P. Rapidfilm( ${ }^{\circledR}$ : An innovative pharmaceutical form designed to improve patient compliance. Int J Pharm. 2010, 393(1-2), 55-60. http://dx.doi.org/10.1016/j.ijpharm.2010.03.055 